\title{
Juha Rikama
}

\section{Kirjallisuustieteellisistä teorioista ja käsitteistä}

Kirjallisuudentutkimuksessa on nykyään kaksi painopistettä. Toisaalta tutkitaan kaunokirjallisten formaattien eli kirjallisuuden esitystekniikkojen ominaisuuksia, toisaalta formaatin avulla tuotettuja merkityssisältöjä. Suurempi painopiste on viime aikoina ollut ehkä formaatin eli tekstuaalisessa tutkimuksessa, mutta myös sisällöntutkimuksen piirissä on tehty arvokasta työtä, esimerkkeinä psykoanalyyttinen, feministinen tai postkolonialistinen tutkimus, joiden menestys on perustunut ennen kaikkea kaunokirjallisten tekstien merkityssisältöjen kontekstien tutkimiseen. Sisältöjen ja kontekstien tutkimus ovat tietysti kehittäneet myös omia spesifejä käsitteitään, mutta formaatin tutkimiseen verrattuna se tulee enemmän toimeen yleiskielen käsitteillä ja lähenee ns. yleiskulttuurista eli maallikkolukijoiden tulkintaa.

Formaatti asettaa tietysti tiettyjä reunaehtoja kirjallisuuden merkityssisällöille, mutta tekstualismin - joka on nykyään formaatintutkimuksen yleisnimike - suuri erehdys on, että formaatti määrää täydellisesti tuotettua merkityssisältöä. Näin olettaminen on kuitenkin puhdasta dogmatismia. Useimmilla lukijoilla on paljon joustavampi, epädogmaattisempi käsitys lukemansa tekstin merkityssisällöstä. Sen mukaan merkitykset eivät sisälly pelkästään tekstiin vaan ne ovat olemassa jo ennen tekstin tuottamista, sen kaikissa konteksteissa eli "ihmisten maailmassa": lukijoiden aiemmissa merkityskokemuksissa ja maailmanymmärryksessä, jotka kirjailija on osannut kiteyttää ja ilmaista konkreettisessa muodossa. Tähän ensi sijassa perustuu kirjallisuuden valtava sosiaalinen ja tiedostuttava merkitys.

Siksi monet väittävät, että jos ensin pitäisi opetella kirjallisuustieteen formaatintutkimuksen käsitearsenaali, kirjailijat tuskin kirjoittaisivat kirjoja ja lukijat tuskin lukisivat niitä. Tie kirjallisuuden rikkaaseen maailmaan ei kulje kirjallisuustieteen formaatintutkimuksen portin kautta vaan kirjallisuuden merkitysten ymmärtämisen kautta.

Äidinkielen opettajain liiton vuosikirjassa 2011 Kirjallisuus liikkeessä - lajeja, käsitteitä, teorioita (toim. Satu Kiiskinen ja Päivi Koivisto) kirjallisuudentutkija Samuli Hägg esittää, että koulun kirjallisuudenopetuksessa on käytettävä tekstualismin tuottamien kirjallisuudentutkimuksen koko teoria- ja käsitearsenaalia ja että tämän täytyy olla ylioppilaskokelaan hallussa hänen ratkoessaan ylioppilastutkinnon kirjallisuustehtäviä. Hänen kantansa perustuu käsitykseen, että yleispäteviä, kaikkien kaunokirjallisten tekstien analysointiin tarvittavia kirjallisuustieteellisiä käsitteitä ei ole olemassa, vaan erilaiset tekstit vaativat erilaisia analyysikäsitteitä, joten ne on hallittava kaikki. Hänen toteamuksensa yleispätevien kirjallisuustieteellisten termien puutteesta on aivan oikea, mutta siitä tehty johtopäätös on tietysti mahdoton toteuttaa toisen asteen koulujen 
kirjallisuudenopetuksen tuntimäärän puitteissa. Se onkin nähtävä lähinnä yliopistojen kirjallisuudentutkimus-oppiaineen reviirin puolustuksena.

Häggin esityksen ongelmana on lisäksi se, että hän ei erota toisistaan kaunokirjallisuuden esitystekniikkaa koskevia ja tällä tekniikalla ilmaistuja merkityssisältöjä koskevia käsitteitä. Jälkimmäiset käsitteet ovat etupäässä yleiskielen käsitteitä ja lähenevät siis em. yleiskulttuurista tulkintaa. Merkitystutkimuksen käsitteet ovatkin helpommin ymmärrettäviä kuin formaatintutkimuksen, niitä maallikkolukijat käyttävät luonnostaan. Kouluopetuksen ongelmana ovat siis ennen kaikkea kaunokirjallisuuden esitystekniikkaa koskevat - eikä niinkään käytetyllä esitystekniikalla ilmaistuja merkityssisältöjä koskevat - käsitteet.

Kirjallisuuden esitystekniikkaa eli formaattia koskevia käsitteitä onkin viime aikoina pidetty tavallisten kirjallisuuden lukijoiden kuten ylioppilaskokelaiden riesana. Syitä tähän ovat muun muassa, että niitä tulee koko ajan lisää, että ne ovat usein keskenään ristiriitaisia ja että ne on oppikirjoissa esitetty kovin epäyhtenäisesti, mikä saattaa oppilaiden yhtenäisen arvostelun vaaraan. Kirjallisuuden merkityksiä oppilaat kuten muutkin maallikkolukijat analysoivat mielellään, ja merkitysanalyysien arvostelukriteerit ovat melko vakiintuneita eivätkä aiheuta suurta arvostelun hajontaa.

Mutta on myös periaatteellisempia syitä, miksi kirjallisuuden esitystekniikkaa koskevat teoriat ja käsitteet ovat ongelmallisia. Nykyään kirjallisuustieteessä hyväksytään teoriapluralismi, useat toisiaan suhteellistavat, joskus myös keskenään ristiriitaiset teoriat. Teoriapluralismia on pidetty merkkinä mm. tutkimuskohteen määrittelykriisistä ja käytettyjen teorioiden vähäisestä selitys- ja tukintavoimasta. Kritiikin perusteluksi viitataan tietoteoriassa selittämisen ihanteena pidettyyn ns. suhteelliseen yksinkertaisuuteen.

Tämän mukaan tieteellinen selittäminen on sitä parempaa, mitä vähemmän erillisiä selitysperusteita eli teorioita saman ilmiöalueen ymmärtämiseen tarvitaan, ja päinvastoin tietoteoreettisesti sitä huonompaa, mitä enemmän erillisiä teorioita tarvitaan. Yksittäinen teoria olisi siten sitä parempi, mitä enemmän ja mitä useamman alueen havaintofaktoja (kirjallisuustieteessä tekstihavaintoja) sen avulla voidaan selittāä, jolloin maksimaalinen selitysvoima olisi ns. "kaiken teorialla". Tosiasiassa nykyisessä kirjallisuustieteessä selittävien teorioiden ja niiden käsitteiden määrä alkaa kuitenkin lähestyä selityskohteiden määrää, kuten Hägg olettaa, mistä seuraa, että kirjallisuudentutkimuksen teorioiden ja käsitteiden selitysvoima alkaa lähestyä minimiä.

Kirjallisuuden formaattia koskevien teorioiden ja termien vähäinen soveltuvuusalue eli yleispätevyyden puute johtaa siis välttämättömyyteen käyttää nimenomaan kirjallisuuden merkitysten analyysissä ja tulkinnassa, joka on etupäässä tulkintaa kontekstien avulla, kaikkia yleiskielen käsitteitä, juuri niin kuin maallikkolukijat tekevät. Voidaanhan tietysti kaikkia yleiskäsitteitä, joita tarvitaan merkitysanalyysissä, sellaisia kuin kriisi, armo tai kohtalo, ruveta kutsumaan kirjallisuustieteellisiksi termeiksi, jos halutaan lisätä analyysin "tieteellisyyttä".

(Kirjoitus on tarkoitettu formaatintutkijoiden kumottavaksi.) 